\title{
NUMERICAL SIMULATION OF THE DEFLAGRATION TO DETONATION TRANSITION IN A TUBE WITH REPEATED OBSTACLES: EXPERIMENTAL SCALE SIMULATION USING THE ARTIFICIAL THICKENED FLAME METHOD
}

Nobuyuki Tsuboi ${ }^{* 1}$ (D) 0000-0002-2784-4620

A. Koichi Hayashi ${ }^{2}$ (D) 0000-0002-4447-6540

Yoshikazu Tamauchi ${ }^{3}$ (D) 0000-0002-4475-335X

Takashi Kodama ${ }^{3}$ (D) 0000-0002-6316-0920

${ }^{1}$ Department of Mechanical and Control Engineering, Kyushu Institute of Technology, 1-1 Sensui-cho, Tobata-ku, Kitakyushu, Fukuoka, 804-8550 Japan

${ }^{2}$ Department of Mechanical Engineering, Aoyama Gakuin University, 5-10-1 Fuchinobe, Chuo-ku, Sagamihara 252-5258 Japan

${ }^{3}$ Safety Department, Safety and Quality Division, Japan Nuclear Fuel Limited, 4-108 Okitsuke, Obuchi, Rokkasho-mura, Kamikita-gun, Aomori, 039-3212 Japan

*tsuboi.nobuyuki318@mail.kyutech.jp

\begin{abstract}
The Artificial Thickened Flame (ATF) method, which involves artificially increasing the flame thickness so as to simulate with a coarse grid resolution, is applied to reduce the computational cost of predicting the Deflagration to Detonation Transition (DDT) in a tube with repeated obstacles. While simulation results depended on the parameter $N$ (the number of grid points in laminar flame thickness), it was found that $N$ values of more than 10 may be excessive. The results show that the chosen simulation method predicts the flame speed as compared to a reference experiment and captures the detail of the strong ignitions near the corner between the obstacle and the sidewall. The present simulation also captures the wrinkle flame front structure during the acceleration of flame.
\end{abstract}

Keyword: detonation, Deflagration-to-Detonation Transition(DDT), Artificial Thickening Flame (ATF), obstacle

Type of the work: Research Article

\section{INTRODUCTION}

The Deflagration to Detonation Transition (DDT) method is one of the methods of initiating detonation by small energy. Early studies [1-2] showed that DDT in a channel can be promoted by installing obstacles. Dorofeev et al. [3] experimented on DDT with obstacles, seeking to better understand the effects of such obstacles on DDT. Frolov [4] studied fast DDT in gas-phase and gas-liquid mixture using experiments and numerical simulations. However, numerical simulation of DDT requires high grid resolution and computational cost, as otherwise it calculates an over-predicted flame speed. To satisfy the requirement of high grid resolution, most simulations use the Adaptive Mesh Refinement 
(AMR) to resolve the flame front locally. Gamezo et al. [5], Ogawa et al. [6], and Goodwin et al. [7] simulated DDT using the AMR technique, seeking to understand the detailed flame propagation and identify the effects of the obstacle blockage ratio. Dziemińska et al. [8] performed DDT simulation without AMR; however, their simulations require fine grid resolution in the whole computational domain. Although AMR is an attractive strategy, a significantly fine grid near the flame front restricts the time step during the simulations, increasing the total simulation cost. Therefore, DDT simulation requires other numerical techniques to reduce the computational cost for the engineering problem.

The underlying concept of the Artificial Thickened Flame (ATF) method [9] is to use a thickened factor in the flame front to control the effects of the diffusion in the governing equations; this can simulate DDT in the laboratory scale without a local refinement technique. This means that the time step during the simulations is not restricted by the significant small grid resolution and DDT simulations using ATF can be carried out impractical computational time. Yu et al. [10] simulated 2D DDT by using ATF to show the ability to predict DDT distance compared to the case without ATF.

The present paper shows the ability to predict the DDT distance in an experimental-scale tube with repeated obstacles, using the ATF method in $2 \mathrm{D}$ and $3 \mathrm{D}$ simulations with the full-chemistry model.

\section{NUMERICAL METHODS}

The governing equations are the two- and three-dimensional compressible Navier-Stokes equations including mass conservation of nine chemical species $\left(\mathrm{H}_{2}, \mathrm{O}_{2}, \mathrm{O}, \mathrm{H}, \mathrm{OH} \mathrm{HO}, \mathrm{H}_{2} \mathrm{O}_{2}, \mathrm{H}_{2} \mathrm{O}, \mathrm{N}_{2}\right)$ and are summarized as follows:

$$
\begin{aligned}
& \frac{\partial \rho}{\partial t}+\nabla(\rho \boldsymbol{u})=0 \\
& \frac{\partial \rho}{\partial t}+\nabla(\rho \boldsymbol{u} \cdot \boldsymbol{u}+p \delta-\sigma)=0 \\
& \frac{\partial E}{\partial t}+\nabla[(E+p) \boldsymbol{u}+\tau \cdot \boldsymbol{u}+\boldsymbol{q}]=0 \\
& \frac{\partial \rho_{i}}{\partial t}+\nabla\left(\rho_{i} \boldsymbol{u}-\rho D_{i} \nabla Y_{i}\right)=\dot{\omega}_{i}
\end{aligned}
$$

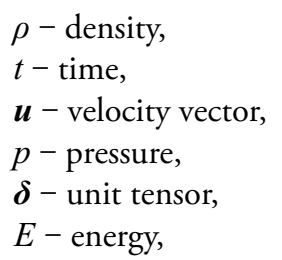

$\tau-$ viscous stress tensor,

$\boldsymbol{q}$ - heat flux vector,

$Y_{i}$ - mass fraction of chemical species $i$,

$D_{i}-$ diffusion coefficient of chemical species $i$,

$\dot{\omega}_{i}-$ production rate of chemical species $i$.

The ATF method uses the following transformation:

$$
\begin{aligned}
\xi & =\mathcal{F} \cdot x \\
\eta & =\mathcal{F} \cdot y \\
\zeta & =\mathcal{F} \cdot z \\
\tau & =\mathcal{F} \cdot t
\end{aligned}
$$


The Navier-Stokes equations including the ATF technique is shown in Eq. (3):

$$
\begin{aligned}
& \frac{\partial \rho}{\partial \tau}+\nabla(\rho \boldsymbol{u})=0 \\
& \frac{\partial \rho}{\partial \tau}+\nabla(\rho \boldsymbol{u} \cdot \boldsymbol{u}+p \delta-\mathcal{F} \tau)=0 \\
& \frac{\partial E}{\partial \tau}+\nabla[(E+p) \boldsymbol{u}+\mathcal{F} \tau \cdot \boldsymbol{u}+\mathcal{F} \boldsymbol{q}]=0 \\
& \frac{\partial \rho_{i}}{\partial \tau}+\nabla\left(\rho_{i} \boldsymbol{u}-\rho \mathcal{F} D_{i} \nabla Y_{i}\right)=\dot{\omega}_{i} / \mathcal{F}
\end{aligned}
$$

$\mathcal{F}$ is called a flame sensor and is a parameter that determines the flame thickness. To remove the excessive numerical diffusion except for the flame region, it is necessary to calculate the appropriate value of $\mathcal{F}$ in the flame region. In the present study, $\mathcal{F}$ is defined by the following equations:

$$
\begin{aligned}
& \mathcal{F}=\max \left(\alpha \mathcal{F}_{1}, 1\right) \\
& \mathcal{F}_{1}=1+\left(\mathcal{F}_{\text {max }}-1\right) \Omega \\
& \Omega=16[c(1-c)]^{2}, c=Y_{\mathrm{H}_{2} \mathrm{O}} / Y_{\mathrm{H}_{2} \mathrm{O}}^{e q} \\
& \alpha=\tanh \left(\frac{\max \left(h_{\text {release }}, 0\right)}{\left(h_{\text {release, } \max }\right)}\right) \\
& \mathcal{F}_{\text {max }}=\max \left(\frac{N \Delta}{\delta_{L}}\right)
\end{aligned}
$$

where $\delta_{L}$ is the laminar flame thickness, $N$ is the number of grid points in the laminar flame thickness, and $\Delta$ is the grid width, respectively. The non-dimensional parameters such as $R e$ and $P e$ are divided by $\mathcal{F}$ when ATF is applied in the governing equations. Therefore, the effects of the diffusion increase and the reaction zone are artificially thickened. The governing equations become the original Navier-Stokes equations for $\mathcal{F}=1$. The present ATF locally acts on the flame region and does not affect the boundary layer and shock wave by using the sensor of the local heat release. The present simulations do not use the turbulent model. The present laminar flame thickness $\delta_{L}$ sets $400 \mu \mathrm{m}$ for premixed hydrogen/oxygen gas under the pressure of $70 \mathrm{kPa}$ and the temperature of $293 \mathrm{~K}$ although $\delta_{L}{ }^{0}=358 \mu \mathrm{m}$. The thickness $\delta_{L}{ }^{0}$ [11] is based on the maximum temperature gradient and is calculated by using the one-dimensional temperature profile for a premixed flame under the present simulation conditions; this thickness is defined as follows:

$$
\delta_{L}{ }^{0}=\frac{T_{2}-T_{1}}{\max (|\partial T / \partial x|)}
$$

where $T_{1}$ and $T_{2}$ are the temperatures in premixed gas and the burned gas, respectively. When the pressure and concentration of fuel in the premix gas are changed, this thickness has to be estimated before the twodimensional and three-dimensional simulations. 
For the convection terms, the AUSMDV scheme [12] is applied. This scheme's spatial accuracy is increased by the second-order MUSCL with the minmod limiter. The third-order TVD Runge-Kutta method [13] is used for time integration. The viscous term is calculated using the second-order central difference. The source term is integrated by the point implicit method. In the present simulation, the detailed chemical reaction model UT-JAXA [14] for hydrogen combustion, containing nine species $\left(\mathrm{H}_{2}, \mathrm{O}_{2}, \mathrm{H}, \mathrm{O}, \mathrm{OH}, \mathrm{HO}_{2}, \mathrm{H}_{2} \mathrm{O}_{2}, \mathrm{H}_{2} \mathrm{O}\right.$, and $\left.\mathrm{N}_{2}\right)$ and 21 elementary reactions, is adopted.

\section{COMPUTATIONAL GRID, SIMULATION CONDITIONS, AND BOUNDARY CONDITIONS}

The present simulation conditions and geometry are based on the experiment of Maeda et al. [15]. The schematic view of the simulation geometry and the computational grid system is presented in Figs. 1 and 2, respectively. The height, width, and length of the rectangular tube are $85 \mathrm{~mm}, 100 \mathrm{~mm}$, and $590 \mathrm{~mm}$, respectively, and these values are the same as the experimental setup of Maeda et al. [15]. The present computational grid systems are summarized in Table 1.

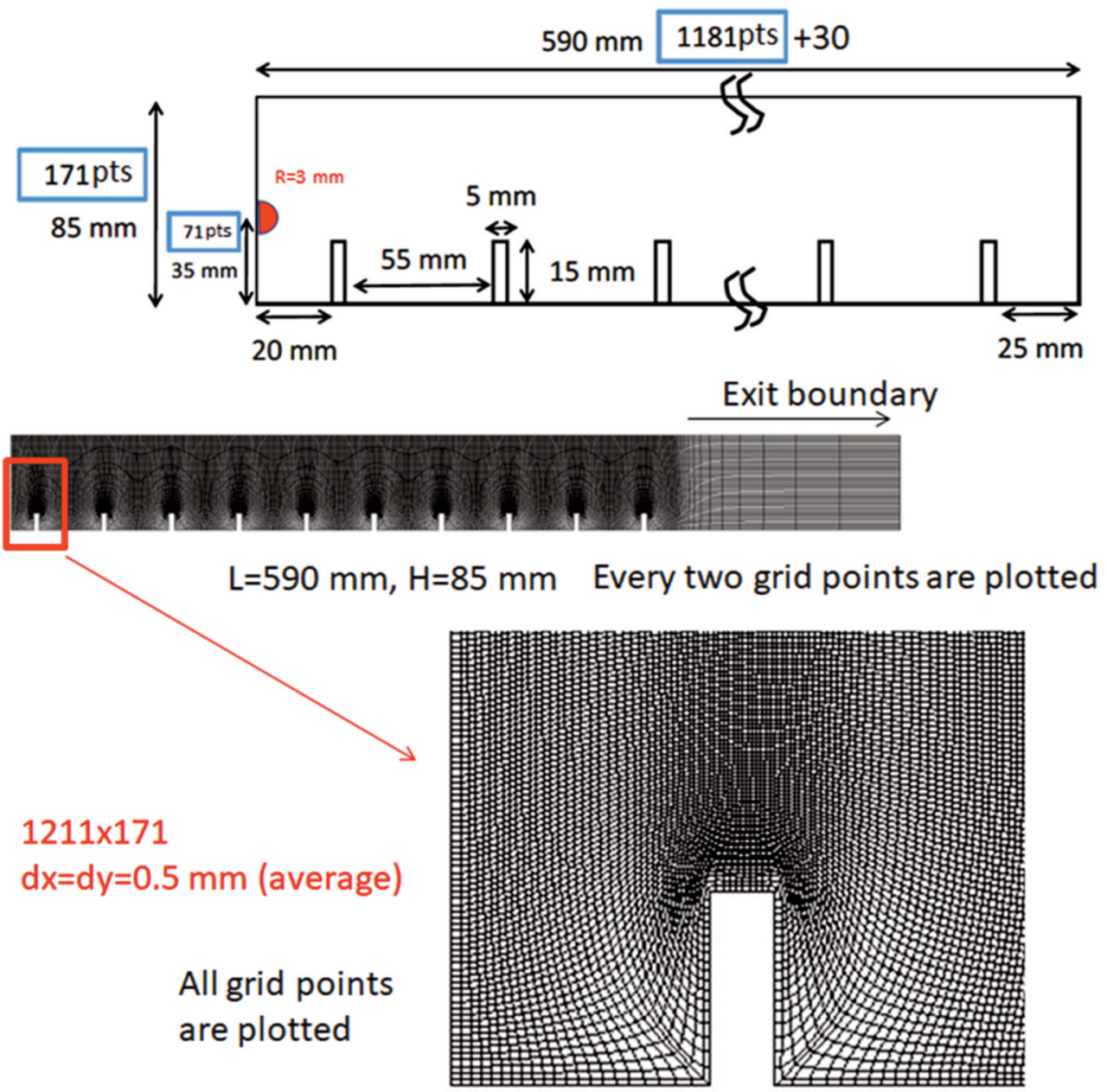

Fig. 1. Example of geometry and computational grid system for Grid 1. 


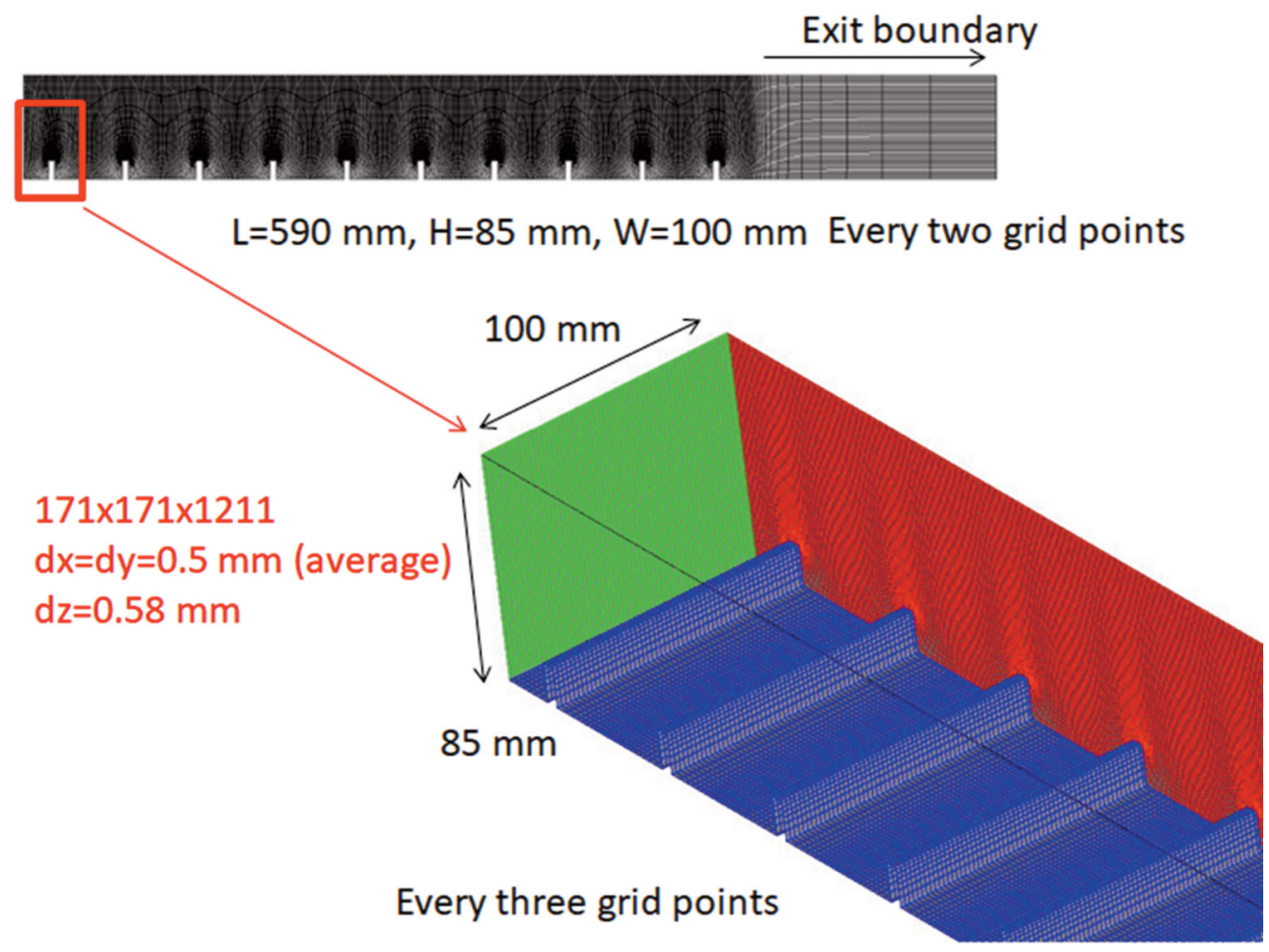

Fig. 2. 3D view of computational grid system for Grid 1.

Table 1. Present computational grid systems.

\begin{tabular}{|c|c|c|c|}
\hline & $\mathrm{i}$ & $\mathrm{j}$ & $\mathrm{k}$ \\
(vertical direction) & (spanwise direction) & (longitudinal direction) \\
\hline Grid 1 & 171 & 171 & 1211 \\
\hline Grid 2 & 227 & 227 & 1614 \\
\hline Grid 3 & 227 & 341 & 2441 \\
\hline
\end{tabular}

The boundary conditions are as follows. The right side boundary is the non-reflected boundary proposed by Gamezo et al. [16]. The other boundaries are the non-slip and adiabatic boundary conditions. As for the initial boundary conditions, the stoichiometric hydrogen/oxygen gas mixture with an initial temperature of $293 \mathrm{~K}$ and initial pressure of $70 \mathrm{kPa}$ is filled in the computational domain and the gas properties are the same as the experiments of Maeda et al. [15]. The ignition source to start this simulation uses a burned gas with a pressure of $70 \mathrm{kPa}$ and a temperature of $3023 \mathrm{~K}$. The mass fraction for each species in this product gas is calculated by NASA CEA. The radius of the burned gas is $3 \mathrm{~mm}$ and the effects of the radius of this ignition source are small in the simulations. 


\section{RESULTS AND DISCUSSIONS}

\subsection{D simulation results and effects of $N$ and grid resolution}

This section first presents the results of the 2D DDT. The computational grid system uses 1211 (longitudinal direction) $\times 171$ (vertical direction) and the average grid width is approximately $0.5 \mathrm{~mm}$. An example of temperature and $\mathcal{F}$ for $N=5$ is presented in Fig. 3. The flame ignited near the left end wall accelerates and a strong ignition appears near the fifth obstacle, to become a detonation. The large value of factor $\mathcal{F}$ exists near the flame front and unphysical fast flame acceleration is suppressed. Figure 4 shows a comparison of the flame tip speed between the experiment [15] and the present simulations for various $N$. This figure shows that $N=10$ provides a better prediction of the flame speed compared to the experimental results, whereas the results for $N=20$ show a slow flame speed and those for $N=5$ show a fast flame acceleration compared to the experiment. The flame speed strongly depends on $N$ and the further 3D simulation uses $N=10$.

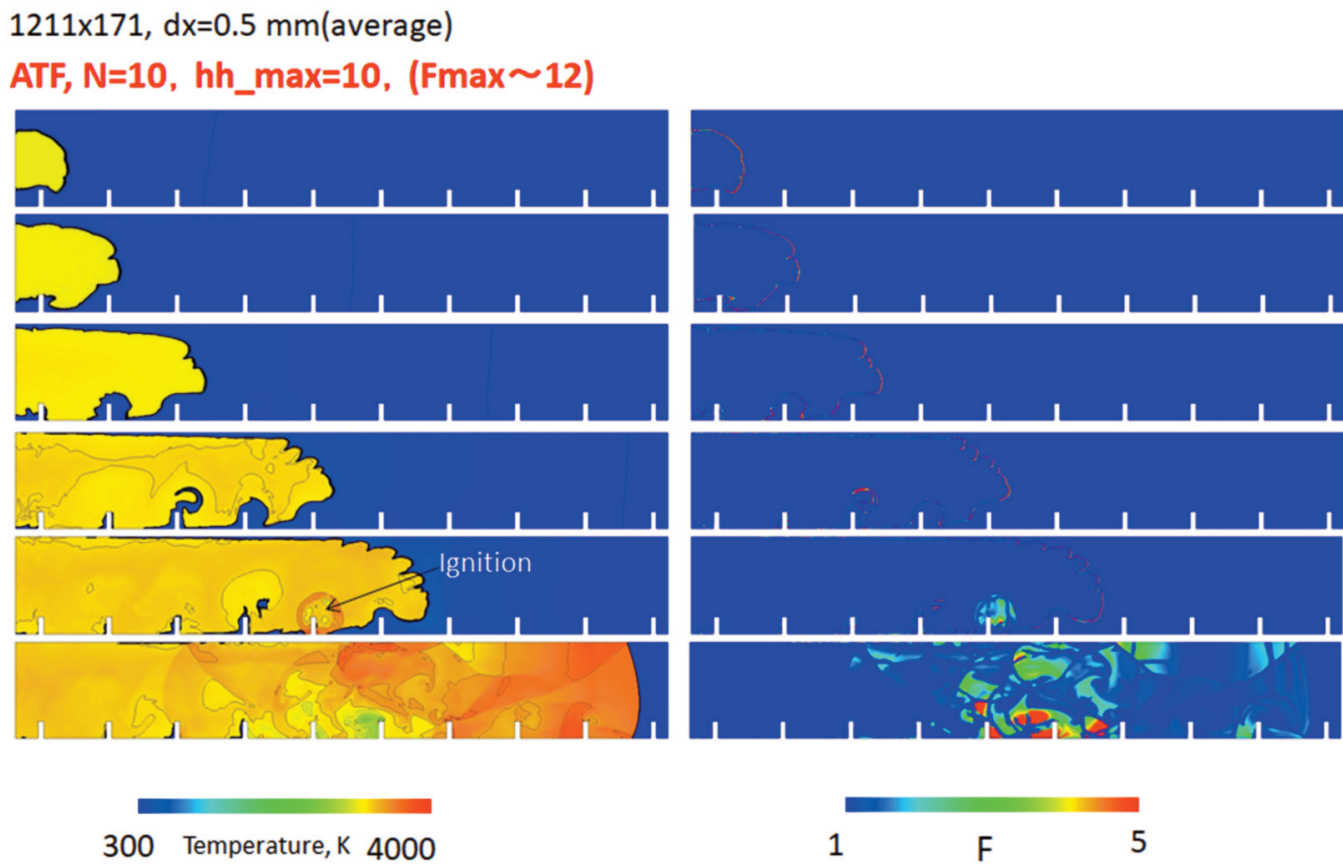

Fig. 3. Instantaneous temperature and $\mathrm{F}$ contours for $2 \mathrm{D}$ simulations.

Figure 5 shows the impact of the grid resolutions on the $2 \mathrm{D}$ simulations. The grid resolution slightly affects the flame speed and ignition position. With increasing grid resolution, the flame speed slightly increases and the ignition position changes near a lower number of obstacles. 


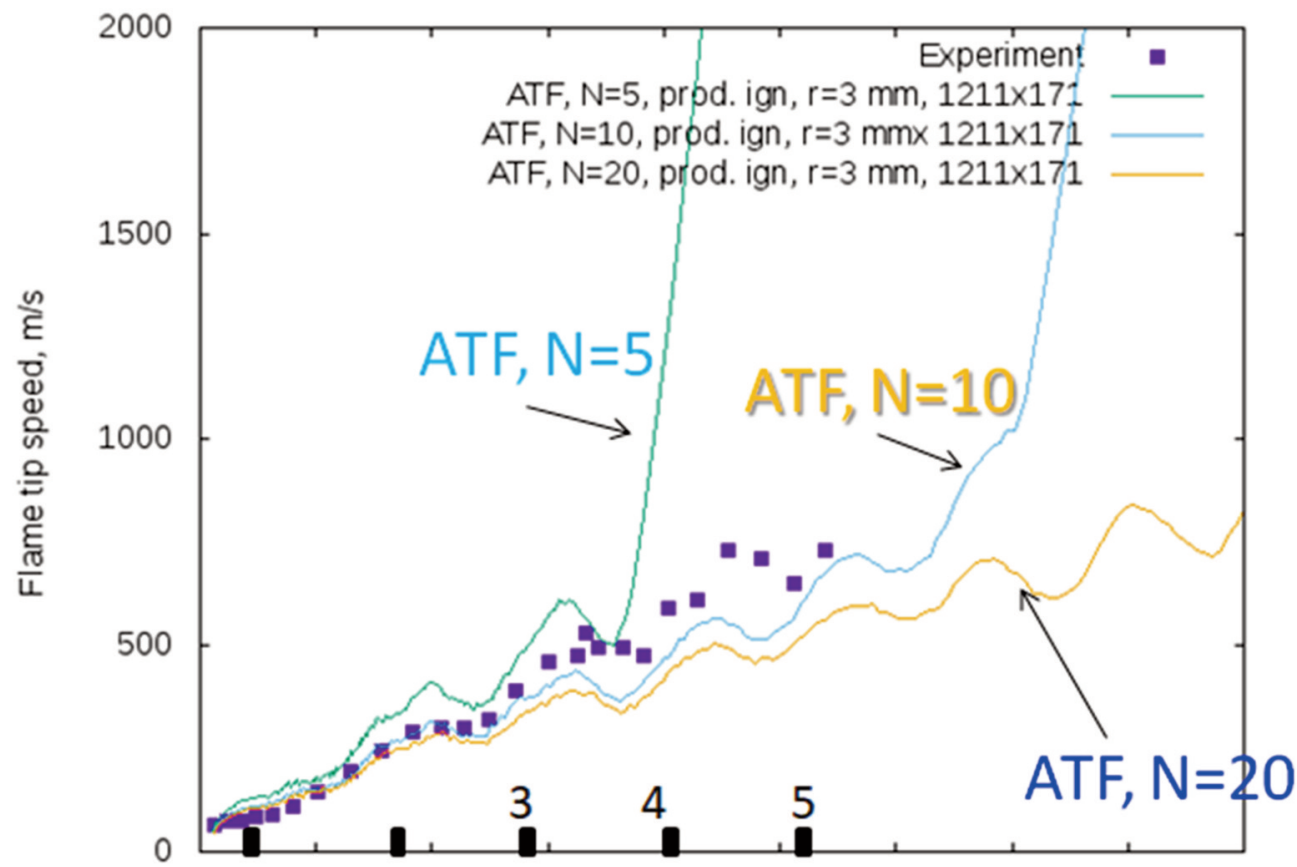

Fig. 4. Comparison of flame tip speed between experiment [15] and the present 2D simulations.

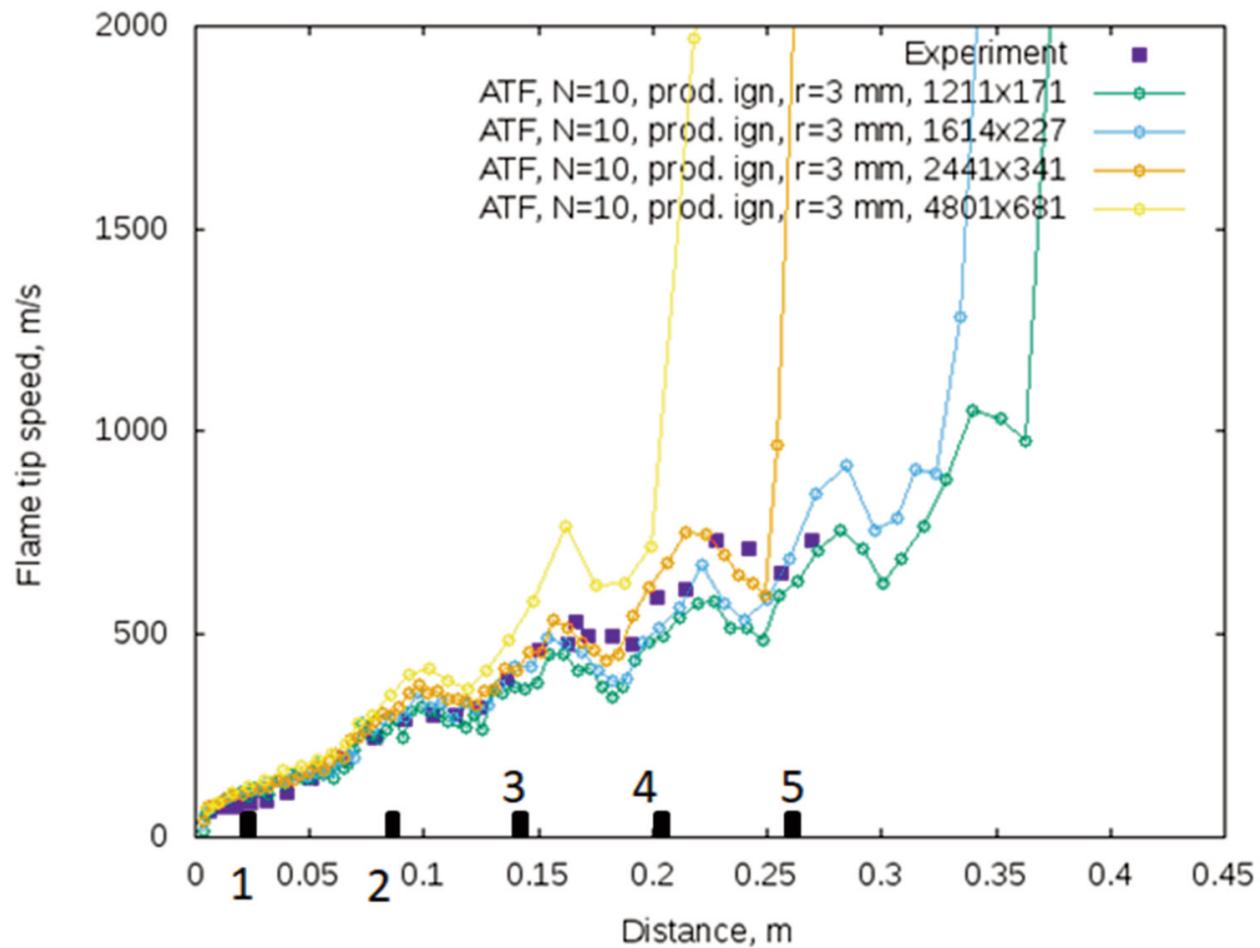

Fig. 5. Effects of grid resolution on flame tip speed for 2D simulations. 


\subsection{D simulation results and effects of grid resolutions}

In this section we present 3D DDT simulations carried out using ATF and examine the grid resolution effects. The parameter $N$ for the ATF is set at 10 . Table 1 shows three different grid resolution systems in the simulation.

Instantaneous density gradient contours for Grids 1 and 2 are shown in Fig. 6. As the flame front accelerates, some weak compression waves propagate in front of the flame front. Both cases show detonation near the 4th obstacle after the initiation. With increasing grid resolution, complicated wrinkles appear on the flame front. Figure 7 shows the side and front view of the instantaneous density gradient and temperature contours. As the flame accelerates, the wrinkles of the flame appear to become complex patterns.
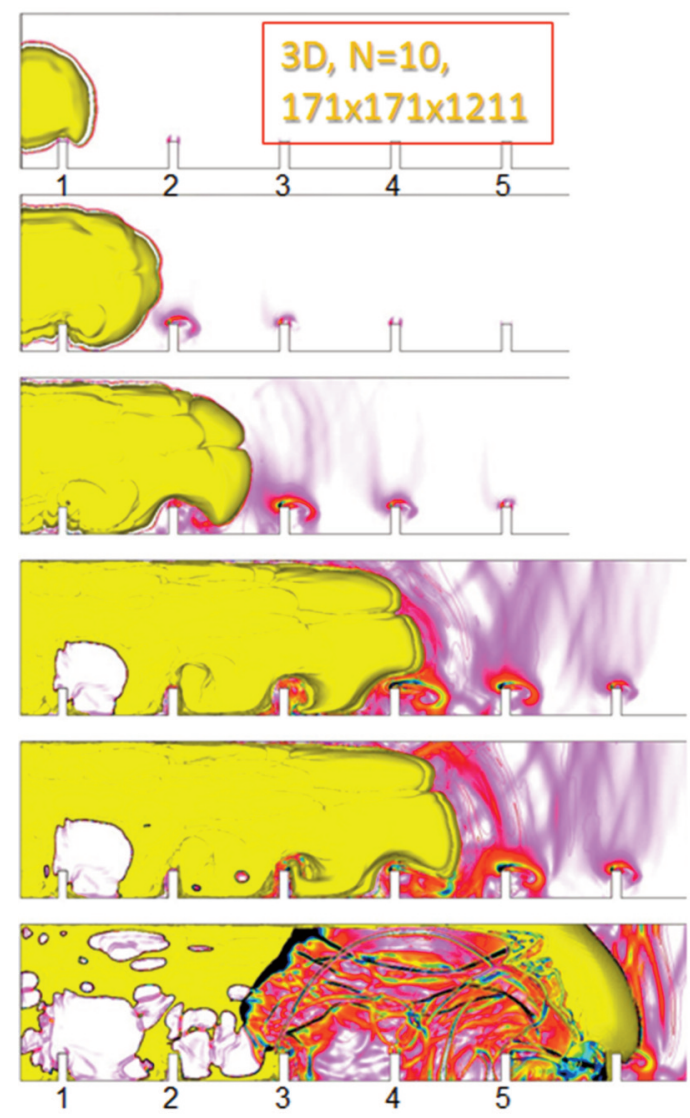

(a) Case 1
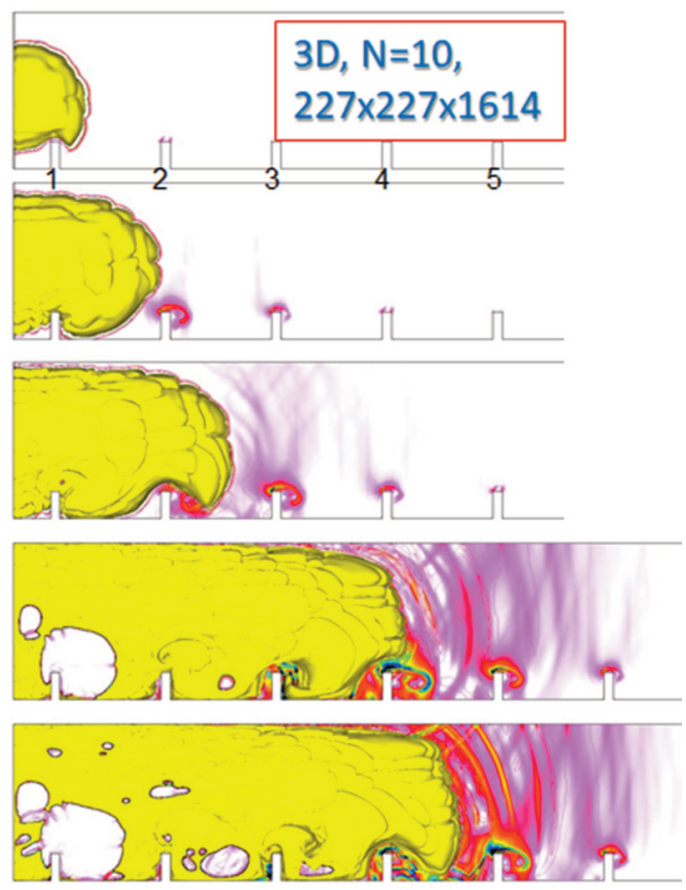

Fig. 6. Instantaneous density gradient contours for Grids 1 and 2. Yellow isosurfaces denote a temperature of $1500 \mathrm{~K}$. 

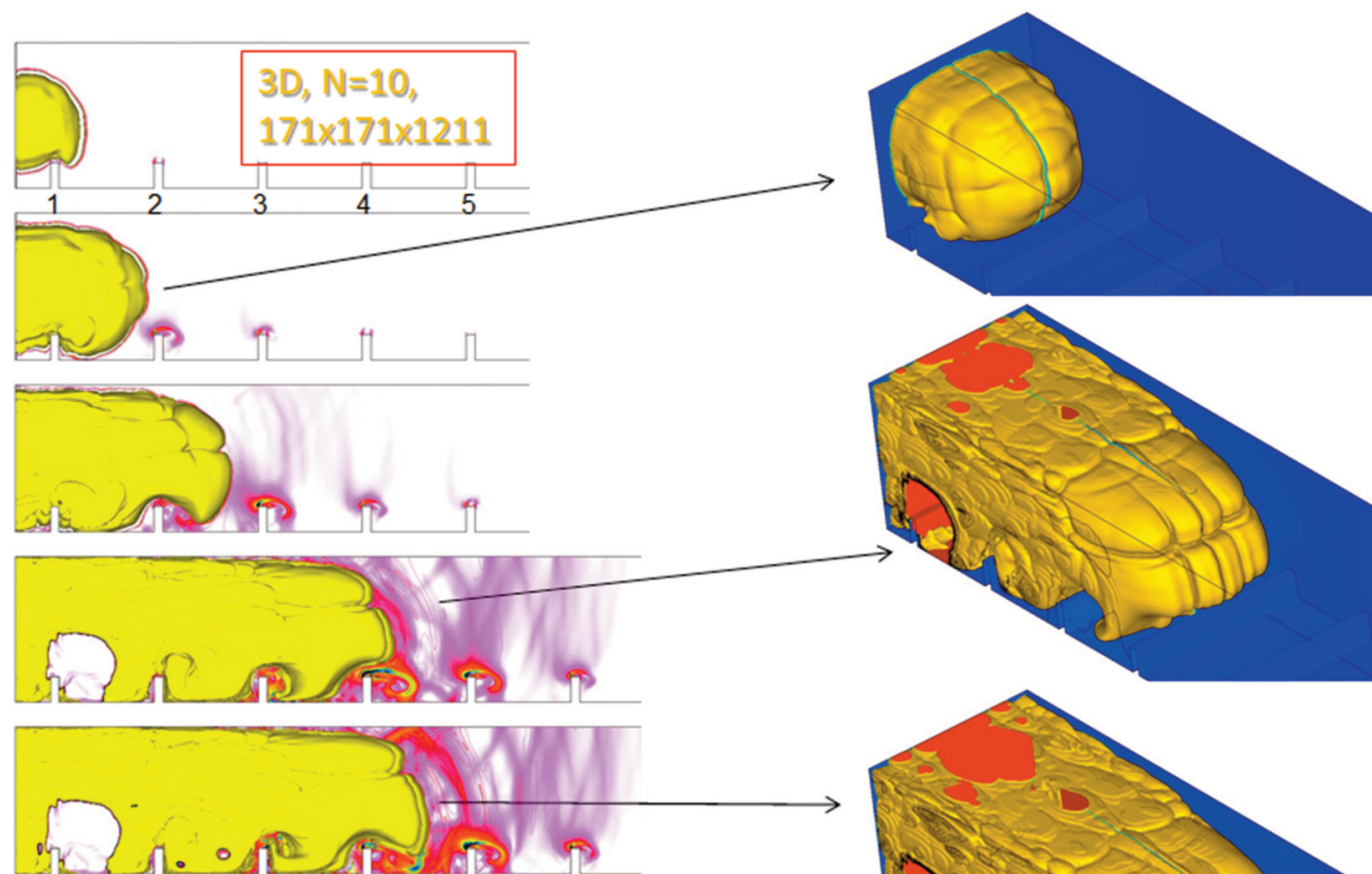

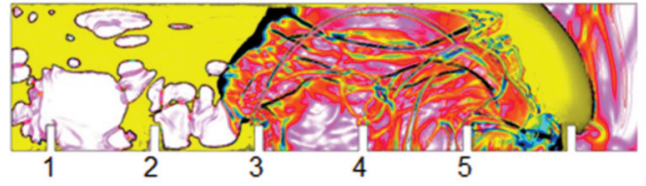

(a) Density gradient

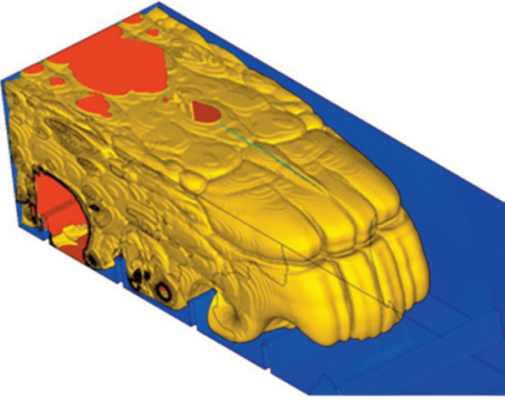

(b) Temperature

Fig. 7. Instantaneous density gradient and temperature contours for Grid 1. Yellow isosurfaces for both figures denote a temperature of $1500 \mathrm{~K}$.

Figure 8 shows a comparison of flame tip speeds between the experiment [15] and the present numerical simulations. The grid resolution affects the flame speed passed at the third obstacle. This figure also shows that the flame speeds between the $2 \mathrm{D}$ and $3 \mathrm{D}$ results with the same grid resolution $(1211 \times 171$ for $2 \mathrm{D}$ and $171 \times 171 \times 1211$ for $3 \mathrm{D}$ ) are different features, with the $2 \mathrm{D}$ results showing slower flame speed than the $3 \mathrm{D}$ results. This is because the $3 \mathrm{D}$ flame propagation is affected by the compression and explosion near the corners of the obstacles.

Figure 9 shows the maximum pressure histories on the tube surface. The strong ignition positions near the corners of the fourth obstacle appear. The detonation initiates by this strong ignition at this position. 


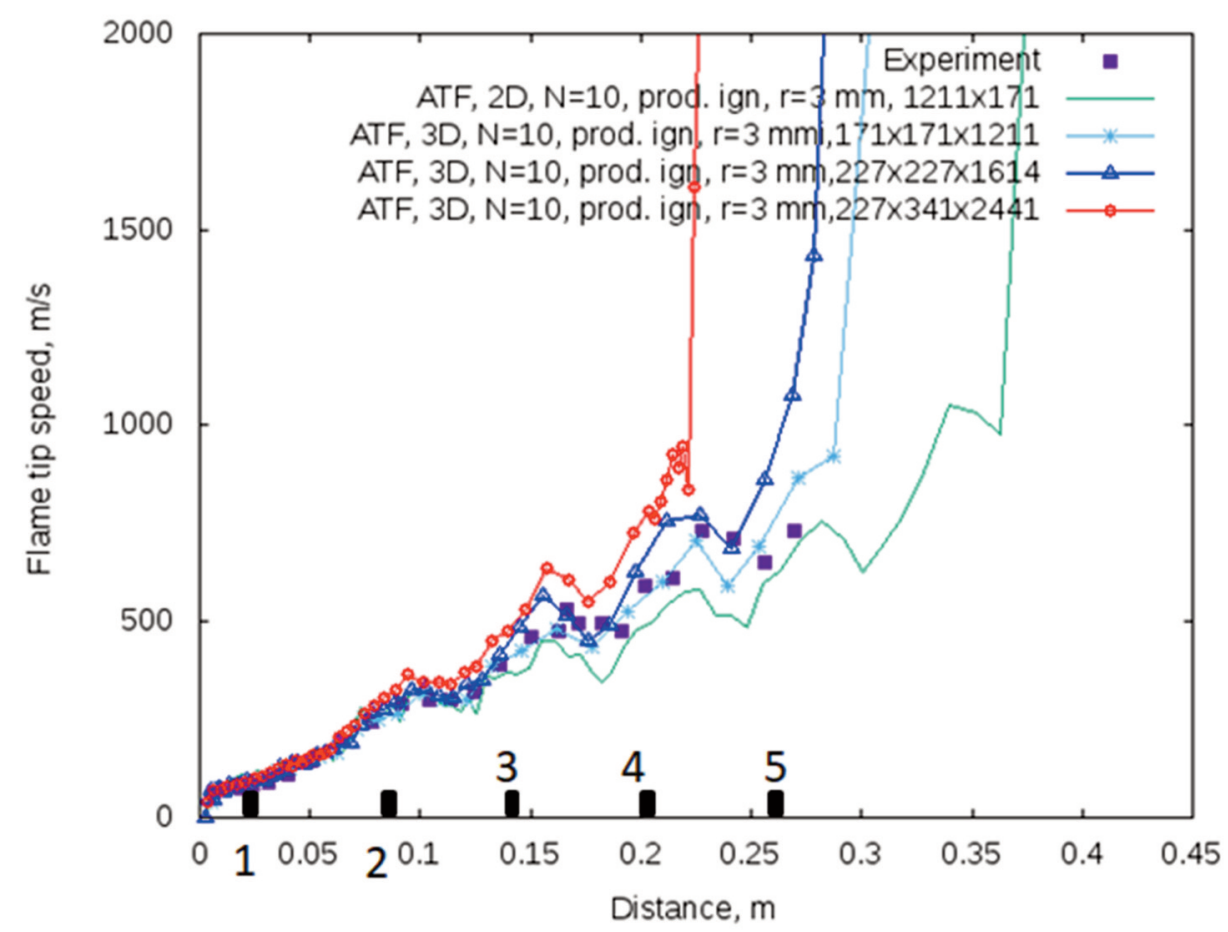

Fig. 8. Comparison of flame tip speed between experiment, 2D simulations, and 3D simulations.

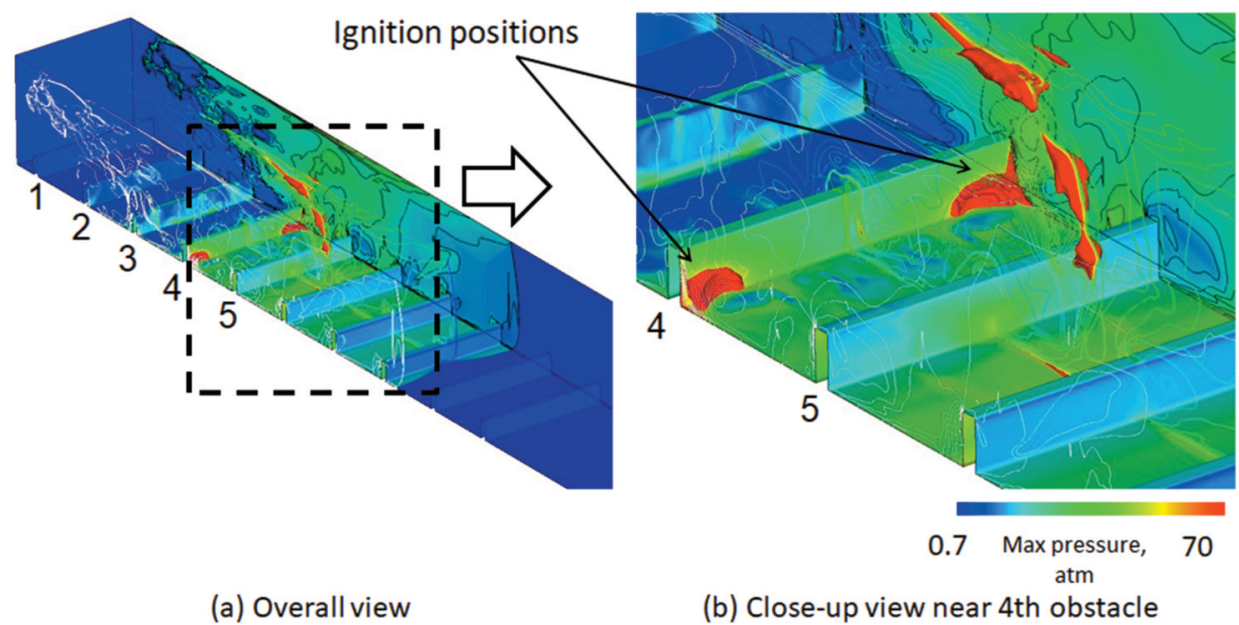

Fig. 9. Maximum pressure histories on tube wall for Grid 1.

\section{CONCLUSIONS}

This paper has presented 2D and 3D DDT simulations in an experimental-scale tube with repeated obstacles, using the ATF method and a detailed reaction model. It was found that although simulation results depend on the parameter $N$ (the number of grid points in laminar flame thickness), the calculated 
results for $N=10$ can predict the flame speed and DDT in the experimental scale. This indicates that $N$ values of more than 10 are excessively large. Moreover, the present DDT simulation was found to depend on the dimension of the simulations, because in $3 \mathrm{D}$ simulation a local ignition starts near the corner of the obstacle and wall. This ignition feature corresponds to the experimental results. The present simulation also captures the complicated wrinkle flame front structure during flame acceleration. The grid sensitivity study for 3D simulation shows that the grid convergence does not obtain with the same $N$, therefore indicating that more grid convergence research is necessary for $3 \mathrm{D}$ as well as $2 \mathrm{D}$ simulation.

\section{Acknowledgments}

The would like to thank Assist. Prof. Ozawa and many previous students in his laboratory. The numerical simulations were carried out by the Supercomputing System at Osaka University and the University of Tokyo. This study is also supported by Japan Nuclear Fuel Ltd.

\section{REFERENCES}

[1] Shchlkin K.I, Troshin Y.K., 1965, Gasdynamics of Combustion. Mono Book Corporation.

[2] Peraldi, O, Knystautas, R., Lee, J.H., 1986, "Criteria for Transition to Detonation in Tubes," Proc. 21st Symp. (Int.) Combust. pp. 1629-1637.

[3] Dorofeev, S. B., Sidorov, V. P., Kuznetsov, M. S., Matsukov, I. D., Alekseev, V.I., 2000, "Effect of Scale on the Onset of Detonations," Shock Waves, 10, pp. 302-315.

[4] Frolov, S. M., 2008, "Fast Deflagration-to-detonation Transition," Russian Journal of Physical Chemistry B, 2(3), pp. 442-455.

[5] Gamezo, V. N., Ogawa, T., and Oran, E. S., 2008, "Flame Acceleration and DDT in Channels with Obstacles: Effect of Obstacle Spacing," Combustion and Flame, 155(1-2), pp. 302-315.

[6] Ogawa, T., Gamezo, V. N., and Oran, E. S., 2013, "Flame Acceleration and Transition to Detonation in an Array of Square Obstacles," Journal of Loss Prevention in the Process Industries, 26(2), pp. 355-362.

[7] Goodwin, G. B., Houim, R. W. and Oran, E. S., 2016, "Effect of Decreasing Blockage Ratio on DDT in Small Channels with Obstacles," Combustion and Flame, 173, pp 16-26.

[8] Dziemińska, E., Fukuda, M., Hayashi, A. K., and Yamada, E., 2012, "Fast Flame Propagation in Hydrogen-Oxygen Mixture," Combustion Science and Technology, 184, pp. 1608-1615.

[9] Butler, T. D., and O’Rourke, P. J., 1977, "A Numerical Method for Two Dimensional Unsteady Reacting Flow," International Symposium on Combustion, 16, pp 1503-1515.

[10] Yu, S. and Navarro-Martinez, S. 2015, "Modeling of Deflagration to Detonation Transition Using Flame Thickening," Proceedings of the Combustion Institute, 35, 1955-1961.

[11] Poinsot, T, and Veynante, D., 2005, Theoretical and Numerical Combustion, 2nd edition, Edwards.

[12] Wada, Y. and Liou, M. S., 1997, "An Accurate and Robust Flux Splitting Scheme for Shock and Contact continuities," SIAM Journal on Scientific Computing, 18(3), pp 633-657.

[13] Gottlieb, S. and Shu, C. W., 1998, "Total Variation Diminishing Runge-Kutta Schemes," Mathematics of Comutation, 67, pp 73-85,.

[14] Shimizu, K., Hibi, A., Koshi, M., Morii, Y. and Tsuboi, N., 2011, "Updated Kinetic Mechanism for High-pressure Hydrogen Combustion," Journal of Propulsion and Power, 27(2), pp 383-395.

[15] Maeda, S., Minami, S., Okamoto, D., Obara, T., 2016, "Visualization of Deflagration-todetonation Transitions in a Channel with Repeated Obstacles Using a Hydrogen-oxygen Mixture," Shock Waves, 26, pp. 573-586.

[16] Gamezo, V. N., Desbordes, D. and Oran, E. S., 1999, "Two-dimensional Reactive Flow Dynamics in Cellular Detonation Waves," Shock Waves, 9(1), pp 11-17. 


\title{
SYMULACJA NUMERYCZNA PRZEJŚCIA PROCESU SPALANIA OD DEFLAGRACJI DO DETONACJI W RURZE Z POWTARZAJĄCYMI SIĘ PRZESZKODAMI: SYMULACJA W SKALI EKSPERYMENTALNEJ Z WYKORZYSTANIEM METODY SZTUCZNEGO POGRUBIONEGO PŁOMIENIA
}

\begin{abstract}
Abstrakt
Metoda sztucznego pogrubienia płomienia (Artificial Thickened Flame-ATF) polega na sztucznym zwiększaniu grubości płomienia w celu symulowania procesu spalania z siatką o dużej rozdzielczości. Metodę tą zastosowano w niniejszej pracy w celu zmniejszenia kosztów obliczeniowych przewidywania przejścia deflagracji w detonację (Deflagration to Detonation Transition - DDT) w rurze z powtarzającymi się przeszkodami. Wyniki takich symulacji zależą od parametru $N$ (liczba punktów siatki w laminarnej grubości płomienia), jednak stwierdzono, że wartości $N$ powyżej 10 mogą być nieracjonalne. Pokazano, że taka metoda symulacji trafnie przewiduje prędkość płomienia w porównaniu z eksperymentem referencyjnym i dobrze wychwytuje szczegóły silnych zapłonów w pobliżu naroża między przeszkodą a ścianą boczną. Obecna metoda pozwala również celnie uchwycić strukturę pomarszczonego czoła płomienia podczas przyspieszania.
\end{abstract}

Słowa kluczowe: detonacja, przejście od deflagracji do detonacji, sztuczne pogrubienie płomienia, przeszkoda 